\title{
1. Evolution of Eastern belief systems
}

This chapter will trace the evolution of Eastern belief systems. It will analyse representative selected scriptures from the East, and look at how these texts have shaped the lives and philosophies of peoples living in the East, influenced thinkers in the West and contributed to the development of the modern principles of human rights. The chapter will begin by examining the content of early scriptures and exploring the relevance of their content for the contemporary world. As Dr Radhakrishnan notes, Hindu and Buddhist scriptures - including the Vedas, the Upanishads, the Bhagavad Gita and the Dhammapada - have done more to colour the minds of the people of the East than is generally acknowledged. ${ }^{1}$

\section{THE ORIGINS, CONTENT AND INFLUENCE OF THE VEDIC PERIOD}

In order to understand deeply entrenched perceptions about human rights in the East and the thought processes of the peoples of the East in relation to human rights, we must explore the sacred texts of ancient times that have influenced the people of the East. The earliest versions of the Rig Veda, ${ }^{2}$ the oldest Hindu scripture, were probably composed around $3000 \mathrm{BC}^{3}$ by a group of Rishis ${ }^{4}$

1 S Radhakrishnan, The Principal Upanishads (edited with an introduction, text, translation and notes) (Harper Collins Publishers, George Allen \& Unwin, London, 2012), p 9.

2 HH Wilson, Rig Veda Samhitaa: A Collection of Ancient Hindu Hymns (WH Allen and Co, Oxford, 1850), (Adamant Media Co, Boston, 2004); Wendy D O'Flaherty, The Rig Veda: An Anthology (Penguin Books, London, 1981); Prasanna C Gautam, Modern English Translation of The Rig Veda Samhitaa (Bharatiya Vidya Bhavan, Mumbai, 2014), Vols I-IV.

3 Based on his analysis of the mantras of the Rig Veda and the events described therein, Gautam explains that the earliest version of the Rig Veda may have been composed in the third millennium BC; Prasanna C Gautam, Modern English Translation of The Rig Veda Samhitaa (Bharatiya Vidya Bhavan, Mumbai, 2014), Vol I, p xxi.

4 A Rishi is someone who acts as a guru, is a learned man, thinker, scholar, author, composer, pundit, priest and adviser to the rulers of the day. A Rishi need not be a Brahmin: anyone can attain the status of Rishi through learning and by understanding the cosmic order and one's place in that order. According to the Bhagavad Gita, a Rishi (or sage) is one who does not become disturbed in their mind when exposed to "the 
(sages or learned men). These sages sought to create an orderly society, to enable people to sing devotional songs and to show the path of the gods through their mantras. Rishis composed mantras or verses that were designed to praise their gods and goddesses, regulate human relationships, organise society and guide human behaviour. These verses also serve to outline the rights and responsibilities of the individual. The Times Atlas of Ancient Civilizations states that the Rig Veda was probably composed towards the end of the period of the Indus Valley civilisation - that is, around 1450 BC. ${ }^{5}$ Citing the Cambridge History of India and the work of other scholars, Griswold also indicates this as the most probable date. ${ }^{6}$ However, many other scholars including Justice Weeramantry ${ }^{7}$ (the former Justice and Vice-President of the International Court of Justice), Tilak, ${ }^{8}$ Jacobi, ${ }^{9}$ Prasanna Gautam ${ }^{10}$ and Devi Subedi ${ }^{11}$ - tentatively attribute this to a much earlier period, around the third to fourth millennium BC. They argue that many of the names and places mentioned in the Rig Veda and other Hindu scriptures allude to locations around the modern-day Caspian Sea region, as well as the names of places and rivers in Iran, and places in Central and West Asia. It is argued that these scriptures existed in their earliest form prior to the supposed migration of the Aryans to the Indus Valley from the Hindu Kush through the Khyber Pass around 2500 BC. ${ }^{12}$

This argument sounds plausible, since there are some similarities between the ancient Iranian (Persian) religion of Zoroastrianism and the content of the Vedas. It is also possible that the original or initial version of the Rig Veda could have been composed in Central or West Asia and brought east

threefold miseries" of becoming elated in happiness, forming attachments and fear and anger; Bhagavad Gita, 2.56.

5 Chris Scarre (ed), The Times Atlas of Ancient Civilizations, Part 6: South Asia (Times Books Limited, London, 1989), p 6. See also Norman Stone et al (eds), Harper Collins Atlas of World History (3rd edition) (Borders Press in association with Harper Collins, Ann Arbor, 1998), p 16.

6 HD Griswold, The Religion of the Rigveda (Oxford University Press, Oxford, 1923), pp 68-73.

7 See CG Weeramantry, An Invitation to the Law (Lawman, New Delhi, 1998), p 12.

8 As cited in HD Griswold, The Religion of the Rigveda (Oxford University Press, Oxford, 1923), p 68.

9 Ibid.

10 Prasanna C Gautam, Modern English Translation of the Rig Veda Samhitaa (Bharatiya Vidya Bhavan, Mumbai, 2014), Vol I, p xxi.

11 Devi P Subedi, Valmiki ra Vyas: Tulanaatmak Anusheelan (A comparative analysis of Valmiki and Vyas), Swadesh Prakashan, Kathmandu, 2016, p 1 (in Nepali).

12 HD Griswold, The Religion of the Rigveda (Oxford University Press, Oxford, 1923), p 73. 
to the Indus Valley and, finally, to the River Ganges basin with the eastward advancement of the Aryan migration. Aryans seem to have originated from areas around the Caspian Sea region, and they documented the names of some of the places they encountered during their long journey to South Asia and adopted elements of local cultures and/or adapted these cultures to their own along the way, incorporating them into the Vedas and other scriptures. According to Griswold, there is a Babylonian influence on the development of Indo-Iranian religious and ethical ideas. ${ }^{13} \mathrm{He}$ adds that:

The language of the Rig Veda is closely akin to that of the Avesta, the Bible of the Zoroastrian religion ... Entire passages of Avesta can be rendered into Vedic and vice versa merely by making the necessary phonetic changes. ${ }^{14}$

But the Avesta is younger than the Rig Veda.

As stated by Gautam, references are made in the Rig Veda to the major battles won by the Aryans in Mesopotamia, and to their journey across the Tigris, Euphrates and Saraswati (the ancient name for a river beginning in the Pamirs area - the Amu Darya (Oxus) or Helmand or Kabul river). Their journey also crossed the Sutlej - a tributary of the Indus (Sindhu) river - and continued via the upper reaches of various rivers originating in the Himalayas. It is believed that the journey of the first group of Aryans to move eastwards from the Indus valley and the modern-day Punjab area along the foothills of the Himalayas brought them first into Nepal and then to the plains of India. ${ }^{15}$ Their civilisation flourished in the fertile valleys of the Ganges, Yamuna, Kali, Gandaki and Koshi. ${ }^{16}$ Among those people who headed eastwards from Mesopotamia (carrying their civilisation) seem to have been the people who called themselves "Aryans" (which means "a noble people of superior class"), who spoke Sanskrit, which means "a refined or sophisticated language". Indeed, Hindu and Buddhist scriptures refer to the Meru or Sumerian mountains; these references are perhaps to an area located within the realms of the Sumerian or Mesopotamian civilisation, which historically covered a region of western Asia situated within the Tigris-Euphrates river system, in the northern part of the Fertile Crescent.

\section{Ibid, p 22.}

Ibid, $\mathrm{p} 65$.

5 Based on an interview with an expert on ancient Sanskrit literature, Dr Devi P Subedi, on 19 July 2020. The contemporaneous notes of the interview are on file with the author.

16 Prasanna C Gautam, Modern English Translation of the Rig Veda Samhitaa (Bharatiya Vidya Bhavan, Mumbai, 2014), Vol I, p xxvii. 
When the early humans migrated out of Africa, one group settled in this region of western Asia. The early civilisation that grew here reached its pinnacle initially in Babylon and later in Persia, and produced two early documents of immense historical significance: the Code of Hammurabi ${ }^{17}$ and the Charter of Cyrus. ${ }^{18}$ These two documents contain the early elements of human rights. When the people from this region migrated in various phases - both east to the Hindu Kush region, the Indus Valley and ultimately the Gangetic plains; and west to Greece and Rome - they carried with them the values of the Sumerian and Babylonian civilisations. Thus, these two historical documents seem to have influenced the values of Islam, Judaism and Christianity when they flourished in the Middle East, from where Christianity spread further west and northwest, ultimately covering much of Europe. Furthermore, these two documents also seem to have influenced the composition of some of the Eastern scriptures of a later period, such as the Upanishads, which advanced ideas similar to those to be found in the Charter of Cyrus. There were various phases of Aryan migration to the East (from Central and West Asia), which played a major role in shaping the values of Hinduism. The early cohort of Aryans to arrive in South Asia from Central and West Asia seems to have composed the Rig Veda, which pre-dated the Code of Hammurabi and the Charter of Cyrus; but those Aryans who arrived later in South Asia seem to have brought with them the values that instigated and led to these historical documents being written, and sought to influence the future direction of Hinduism.

In an article on the origins of human rights written for the British Foreign \& Commonwealth Office in 2015, Greg Dorey states that:

Human Rights are sometimes portrayed as a "Western" concept or invention (usually most vociferously by those committing the most serious violations). This is, in fact, a misreading of centuries of history which led up to the adoption of the Universal Declaration of Human Rights in 1948. Way back in 539 B.C., the armies of Cyrus the Great, the first king of ancient Persia (modern day Iran), conquered the city of Babylon. In doing so, and as he prepared to govern his new territory, he

17 The tenets of the Code of Hammurabi proclaimed by the Babylonian king Hammurabi, who reigned from 1792 to $1750 \mathrm{BC}$.

18 The Charter of Cyrus the Great (who ruled Persia from 559 to $529 \mathrm{BC}$ ), was written on a baked-clay Aryan language (Old Persian) cuneiform cylinder. In the Charter, after introducing himself and his ancestors, Cyrus says that he is the monarch of Persia, Babylon, and the four directions and declares that: "Now that I put the crown of kingdom of Persia, I announce that I will respect the traditions, customs and religions of the nations of my empire and never let any of my governors and subordinates look down on or insult them. I will impose my monarchy on no nation. Each is free to accept it, and if any one of them rejects it, I never resolve on war to reign. I will never let anyone oppress any others, and if it occurs, I will take his or her right back and penalize the oppressor ... Today, I announce that everyone is free to choose a religion." 
declared that slaves would be free, people had the right to choose their own religion, and that different races living in the city would be treated equally.

He goes on to add:

Cyrus' ideas, which played an important role in developing the concept that human rights are not limited to one cultural tradition, would be built upon by other great civilisations in the coming centuries. The Edicts of Ashoka, 33 inscriptions recording laws set down by the Emperor Ashoka of the Mauryan Empire between 273 and $232 \mathrm{BC}$, can be found across modern-day Bangladesh, Nepal, India and Pakistan. $\mathrm{He}$ is credited with promoting tolerance and understanding between religious communities, humanitarian ideals in warfare and the right to a fair trial. Some centuries later, the Prophet Muhammad would draft the Charter of Medina (c.622), which some academics have argued was the first constitution to enshrine a set of basic human rights. ${ }^{19}$

Many practices and beliefs, such as fire-worshipping, are common in the Zoroastrianism of ancient Persia and in Hinduism. This also demonstrates a link between the Hindu Aryans and the Zoroastrians. Cyrus the Great himself was a Zoroastrian; but he did not seek to impose his belief on his subjects residing within his vast empire - he let them enjoy whatever faith or belief they had. Thus, it can be submitted that since the early root of all major civilisations and human rights was West Asia, the idea of human rights is both Eastern and Western in origin, and hence universal.

\subsection{The Influence of the Vedic Period on other Civilisations and Vice Versa}

There are many similarities between the Sumerian and Vedic cultures. As is seen in the structure of the Sumerian culture, a priestly class - known as Brahmins - enjoyed a powerful status in Vedic society due to their intellectual knowledge, passed down through centuries of learning, and their mastery of certain skills. Brahmins played a similar role to the one played by the literary elite of the Sumerian culture: they composed scriptures and codes of conduct known as Smritis and Shrutis. Furthermore, they retained the right to interpret these scriptures; they acted as judges (known as "dharmadhikari") in the community, and they played a central role in nominating their kings. The discovery in recent years of identical stamp-seals located in the Sumerian city of Ur and in the Indus valley suggests that the Vedic society was perhaps an offshoot of the Sumerian civilisation or the Sumerian and Indus Valley civilisations,

19 Greg Dorey, "Human Rights and the Cyrus Cylinder", 3 March 2015, https:// blogs.fco.gov.uk/gregdorey/2015/03/03/human-rights-and-the-cyrus-cylinder/. 
with which it once had direct contact. ${ }^{20}$ Like the Hammurabi of Babylonian times, the Vedic people appear to have incorporated, emulated and surpassed Sumerian and Babylonian cultural practices through their use of the Vedas and other scriptures; but they retained some Sumerian and Babylonian values, manners and customs within their own culture.

Gautam notes that:

Contrary to the widely held view that the Vedas had developed following the ancient Greek invasion of India, many scholars from the East and the West have implied that it was the knowledge of the Vedas which had subsequently inspired the ancient Chinese, Egyptian and Greek civilizations.

Gautam cites examples taken from the work of scholars such as French author Georges Ifrah, American linguist Leonard Bloomfield, German Indologist Leopold von Schroder, French philosophers Roger-Pol Droit and Francois M Voltaire, Japanese philosopher Professor Orakura, and Chinese philosopher and writer $\mathrm{Hu}$ Shih. ${ }^{21}$ Indeed, Justice Weeramantry also states that "Hindu philosophy is older than the Greek or Chinese"; and that it is "well accepted from linguistic evidence that Sanskrit, the ancient classical and sacred language of the Hindus, in which the Vedas were composed, is the oldest known member of the Indo-European family of languages". ${ }^{22}$

In his analysis, Justice Weeramantry cites scholars such as Fritz Berolzheimer, who suggest that Hindu philosophy was one of the mainsprings of the philosophical ideas of the Greeks. ${ }^{23}$ Scholars such as Sastry state that the mother of all religions was Hinduism. ${ }^{24}$ Weeramantry also argues that cultures such as the Hindu-Vedic-Aryan culture were already old when ancient Greek civilisation was still in its infancy. ${ }^{25}$ When Socrates - the renowned thinker and philosopher who helped to found the cultures of Western civilisations - was sharing his ideas with pupils such as Plato, and when Plato wrote classic works

20 See CG Weeramantry, An Invitation to the Law (Lawman, New Delhi, 1998), p 9.

21 Prasanna C Gautam, Modern English Translation of the Rig Veda Samhitaa (Bharatiya Vidya Bhavan, Mumbai, 2014), Vol I, p xxii.

22 CG Weeramantry, An Invitation to the Law (Lawman, New Delhi, 1998), p 13.

23 The World's Legal Philosophers, Modern Legal Philosophy Series, Vol 2, p 37, as cited in CG Weeramantry, An Invitation to the Law (Lawman, New Delhi, 1998), p 13 .

24 KRR Sastry, "Hinduism and International Law", 117 Recueil des Cours (1966-I), p 507.

25 See CG Weeramantry, An Invitation to the Law (Lawman, New Delhi, 1998) p 17. 
such as The Republic ${ }^{26}$ and The Laws, ${ }^{27}$ Hindu civilisation was already well advanced; and both Buddha and Krishna had already imparted their philosophies of life through the Tripitaka and the Bhagavad Gita respectively, which, it is argued, are based on the much older Vedas and Upanishads.

It appears that the Aryans perfected their culture after arriving in the modern-day Punjab area and dislodging the people who had developed the Indus Valley civilisation. Although Jacobi and Tilak put the date of the composition of the Rig Veda at 4500-2500 BC, on the basis of astronomical calculations, and Bloomfield is also inclined to put the date at $2000 \mathrm{BC},{ }^{28}$ it has generally been submitted by both Western and Eastern scholars that the current version of the Rig Veda was composed in approximately c 1450 BC. It was followed by the composition of three other Vedas and many Upanishads. Indeed, there are some similarities between the works of Plato and Hindu scriptures regarding matters such as the immortality of the soul and the organisation of society along the lines of class, according to a caste system. Plato speaks of three social classes: the Perfect Guardians, the Auxiliary Guardians and the Third Class. ${ }^{29}$ The status of the Perfect Guardians resembles that held by the Brahmins in Hinduism. The status held by the Auxiliary Guardians resembles the status of the Kshatriyas (the second-highest caste in Hinduism). These two classes of Guardians were supposed to rule in unison, which is similar to how the Brahmin-Kshatriyas ruled under the Hindu system.

The Third Class resembles the third Hindu caste of the Vaishyas: those people who work in agriculture, in the trades, in commerce and in the service sector. However, the main difference between the two systems is that Plato's Third Class encompasses everybody apart from those in the intellectual classes - that is, the Perfect Guardians and the Auxiliary Guardians; while in Hinduism, a fourth class exists, which mainly comprises people who do menial jobs in the service sector. When the Aryans conceived the caste system, they did so on the basis of the colour of the skin and the profession of the people. Thus, the aboriginal non-Aryans of darker skin were initially put in the fourth caste; but when the caste system was reorganised later, they were integrated into all four castes depending on their profession and heritage. Slaves were not acknowledged as being part of the social hierarchy of Hinduism and likewise

\footnotetext{
26 Desmond Lee (translated with an introduction), Plato: The Republic (Penguin Books, Middlesex/New York, 1974).

27 Trevor J Saunders (translated with an introduction), Plato: The Laws (Penguin Books, Middlesex/New York, 1975).

28 As cited in HD Griswold, The Religion of the Rigveda (Oxford University Press, Oxford, 1923), p 69.

29 Desmond Lee (translated with an introduction), Plato: The Republic (Penguin Books, Middlesex/New York, 1974), Parts II and IV.
} 
are not mentioned as a class in the works of Plato; they are thought of as mere appendages to the other classes.

There is no credible evidence to suggest that Socrates, Plato or Aristotle was influenced by the scriptures of Eastern civilisations. However, it is possible that the cultures of ancient South Asia were studied by ancient Western civilisations. Western philosophers of the classical Greek and Roman periods would have known how the ancient states in South Asia was governed, because there is evidence of interaction between peoples living along the fertile Indus Valley and the Gangetic plains and the Greeks and the Romans. One plausible scenario which accounts for cultural similarities between the East and the West is that both Eastern and Western philosophers came up with similar ideas about the organisation of society simultaneously, but independently of each other, and that their ideas were informed by each civilisation's heritage. For example, Kautilya, the author of the Arthashastra,${ }^{30}$ was a contemporary of Aristotle, and the detailed rules prescribed for different classes or castes represented in the Arthashastra are also present in the earlier scripture, the Manusmriti. These rules have many similarities with The Laws of Plato. However, both the Arthashastra and the Manusmriti clearly mention and are influenced by much earlier Hindu scriptures, including the Rig Veda.

\subsection{The Contribution of the Vedas and the Upanishads}

According to most authors, including Griswold ${ }^{31}$ and Radhakrishnan, ${ }^{32}$ the Rig Veda is the oldest Indo-European literary monument. The word "Veda" is taken from the word "Vid", which means "to know" in Sanskrit, in the context of knowledge par excellence and sacred wisdom. ${ }^{33}$ Griswold adds that since the Rig (or Rik) is the name for laudatory verse or stanza, the compound word "Rig Veda" may be translated as "Verse-Wisdom". ${ }^{34}$ He sums up the significance of the Rig Veda as follows:

Like the gleaming of the Himalayan snows to the traveller on the plains is the morning beauty of the Rig Veda, more attractive, if possible, to our hearts than the

30 LN Rangarajan, Kautilya: The Arthashastra (edited, rearranged, translated and introduced) (Penguin Books, New Delhi/London, 1992).

31 HD Griswold, The Religion of the Rigveda (Oxford University Press, Oxford, 1923), p 75.

32 S Radhakrishnan, The Principal Upanishads (edited with an introduction, text, translation and notes), (Harper Collins Publishers, George Allen \& Unwin, London, 2012), p 28.

33 Ibid, p 29.

34 HD Griswold, The Religion of the Rigveda (Oxford University Press, Oxford, 1923), p 54. 
dazzling splendour of the Homeric poems. It is the whole of the picture - the people, the poetry and the faith it reflected in it - that captivates our hearts. ${ }^{35}$

The code of human conduct prescribed in the Rig Veda is known as the Rita or the Moral Laws, upon which the contemporary religion known as Sanatana Dharma is based. There are 10552 mantras composed in classical Sanskrit in the Rig Veda, many of which are included in other Vedas that were composed later. The Rig Veda contains instructions for the various actors who played a significant role in ancient society. It instructs rulers about forming an orderly society, leading a spiritual life, imparting wisdom, history, philosophy and prayers. It does not focus on the Hindu religion in detail, but talks about man's creation, social organisation and spiritual rituals, including the worship of nature and fire; it shares thematic elements with the pagan rituals of worship followed by many other ancient civilisations. The followers of the Vedic religion (the Aryans) believe that the Rig Veda is the main source of all spiritual knowledge. Indeed, the Indian Nobel laureate Rabindranath Tagore describes the Rig Veda as "a poetic testament of a people's collective reaction to the wonder and awe of existence". ${ }^{36}$ In summary, the Rig Veda is a framework scripture from which emanated three other Vedas and 108 Upanishads. From these texts, many Shrutis, Smritis and Puranas were composed later by recognised scholars numbering upwards of 2000, in order to flesh out and expound on the knowledge presented in the Rig Veda.

The values of Hinduism that we understand today did not descend on civilisation as fully blown ideas. The development of Hinduism has taken centuries of painful trial and error, with reform and revision along the way. Some Hindu values can be traced back to the very distant past; while others can be traced back through many phases of evolution, reform and revision. Just like the scriptures of most other ancient religions, the Rig Veda contains verses that worship fire, the sun and the other major elements of nature. Weeramantry explains as follows: "Early men, looking with wonder on his universe, saw it inhabited and controlled by beings welding power that far exceeded his own. ${ }^{37}$ Many of the earliest religions began by worshipping the powerful forces of nature, including the sun, the moon, fire, mighty rivers and majestic mountains. The same pattern can be seen in the Rig Veda.

There are four significant ancient Vedas: the Rig Veda, the Yajur Veda, the Sama Veda and the Atharva Veda. However, the Rig Veda is now classed as

Ibid, p 373.

36 As cited in CG Weeramantry, An Invitation to the Law (Lawman, New Delhi, 1998), p 12.

$37 \quad$ Ibid, p 5. 
the principal and most influential Veda. ${ }^{38}$ It forms the basis of most Eastern philosophies. Parts of it are concerned with the organisation of society. However, with the gradual growth of the population and the development of human ingenuity of all kinds - including the intellectual evolution of the concepts of crime, adultery and incest - the early Vedic people included verses in all their Vedas, and in other scriptures, which defined the duties of an individual person and of householders and households towards each other. This became the origin of the theory of dharma in Hindu philosophy. Other prescriptions dealing with personal and communal hygiene and sanitation were also adopted to promote healthy living, and these were also subsumed within the philosophy of dharma. As society developed, social problems became more numerous and new rules were designed to regulate personal conduct. Thus, the Vedas continued to be revised by successive generations of Rishis in order to reflect contemporary realities of life. Most of the values of Hinduism and Buddhism (in their embryonic form) emanate from the Rig Veda. Indeed, the Rig Veda is the first scripture known to us that came into existence in ancient Asia; it was translated from Sanskrit into English by Professor Wilson, the first Professor of Sanskrit at Oxford, in 1850.

There are two different strands of thought about the origins of the people who composed the Vedas and those who followed up on this work. These people called themselves Aryans, which translates as "noble or superior". The ruling elites among this group called themselves Devas (if they were men) and Devis (if they were women). Intellectual elites in the group were known as Rishis. The Devas and Devis consider themselves to be gods or goddesses, but they did ascribe divine qualities to themselves. In this tradition, the characters of Rama, Krishna and Buddha evolved as human beings that were somehow distinguished from other people and had divine qualities, but they were not elevated as gods during their lifetime. They were treated as gods later by the Hindus, since it was a tradition in Hinduism to regard a person with divine qualities as a god. In the Bhagvad Gita, Krishna says that he was the greatest of all human beings, but was later worshipped as a god by the followers of his teachings. Various gods and goddesses themselves believed in the supreme God, the Almighty, called Ishwar (ईश्वर), who had no form or shape; and there was only one Ishwar for all human beings.

Among ordinary people, the Brahmins enjoyed the highest status in the social strata as defined by the Rig Veda, because they were men and women of learning and teaching, and were responsible for leading prayers and conduct-

38 See generally A Barth, The Religions of India (authorised translation by Rev J Wood) (S Chand \& Co, New Delhi, 1969); F Harold Smith, Outline of Hinduism (Epworth Press, London, 1934), ch 1. 
ing religious ceremonies. However, persons from any class could rise to the status of Rishi by merit of their intellectual prowess and status, and this status was higher than that of an ordinary Brahmin.

One strand of thought argues that the Aryans (or Hindus, as they were later known) were local indigenous people who resided in and around the Indus Valley, the River Ganges basin and the upper reaches of the snow-fed rivers of the Himalayas, including modern-day Nepal. ${ }^{39}$ It is thought that they developed as a people over millennia, becoming more advanced than the other peoples living around them because of their sophisticated application of Vedic knowledge and practices. Another strand of thought, which is now considered more valid, argues that the Aryans (followers of the Vedas or the Sanatana Dharma, or Universal Moral Code) were originally from the Caspian Sea region and migrated eastwards via what is now modern-day Iran and Tajikistan, into the Indus Valley, passing through the Hindu Kush and through the Khyber Pass, and gradually progressing to the River Ganges basin. Scientifically, this version of origin has become more plausible.$^{40}$ Here, the reader should note that the term "Aryans", as it is used in the context of this current analysis, is very different from the use of the same term made infamous by Nazi Germany in the twentieth century in order to claim superior status for the Germanic peoples. The same can be said about the use of the ancient Hindu symbol of wisdom and prosperity, the Swastika.

\footnotetext{
39 See, for example, GD Bakshi, The Sarasvati Civilization (Garuda Prakashan, Haryana, 2019).

40 When the present author - a Brahmin of the so-called Aryan race from the foothills of the Nepal Himalayas - enlisted the help of a reputable genome mapping company in the US to trace his ancestry, it led to north India and then to the Indus (Sindhu) River Valley region and Central Asia, but not beyond. Although genome mapping does not go very far back in history to ascertain the journey of ancestors in the very distant past, the available data may be interpreted to mean that the Aryans were local to the Indus valley or modern-day Punjab. If they were migrants, they did not originate from very far outside of the Hindu Kush region. The report from the US genome mapping company was produced in 2019 after analysing a sample provided by the present author.
} 
Whatever the original date of its composition, ${ }^{41}$ or whether the Aryans were migrants ${ }^{42}$ to South Asia or indigenous peoples, ${ }^{43}$ the Rig Veda was expanded, refined and revised by succeeding generations of Rishis over the centuries, as the Aryan civilisation advanced and their migration continued eastwards. Much later, the Rig Veda was ultimately divided into four Vedas during the Puranic period by an intellectually gifted Rishi called Krishna Dwaipayan, who later came to be known as Vedabyasa (meaning "the one who expanded the Vedas"). The composition of the other three Vedas ${ }^{44}$ draws heavily on the Rig Veda and was undertaken during the Puranic period, which saw the emergence of the Hindu version of the Creation ${ }^{45}$ and the early history of mankind. ${ }^{46}$ However, before then, the expansion, refinement and amendment of the Vedas had been undertaken for centuries ${ }^{47}$ by scholars known as Byasas, who worked prior to the birth of Krishna Dwaipayan. The term "Byasa" means "compiler" and describes a learned man who specialises in compiling scriptures. The work

41 By all accounts, the Rig Veda is older than the Avesta; the Iranian (Persian Gatha), and the original version of the Rig Veda could very well have been composed in the territory of modern-day Iran.

42 John Keay states that the Indo-Aryans were probably outsiders. This is the prevailing view among most commentators on Asia. See John Keay, India - A History: From the Earliest Civilisations to the Boom of the Twenty-First Century (Harper Press, London, 2010), p xxvi.

43 BB Lal, The Rigvedic People: Invaders? Immigrants? or Indigenous? (Aryan Books, Delhi, 2015), Professor Lal was the Director General of the Archaeological Survey of India from 1968 to 1972.

44 An important Purana, the Shrimad Bhagavatam, states that the Vedabyasa divided one Veda into four Vedas; see verse 21, ch 3, first canto of Shrimad Bhagavatam: Bhaktivedanta Swami Prabhupada, Shrimad Bhagavatam (The Bhaktivedanta Book Trust, Watford, 2006), p 165.

${ }_{45}$ The Rig Veda d escribes the Creation in the following words: "हिरण्यगर्भ: समवर्तताग्रे भूतस्य जातः पतिरेकासीत। सदाधार पृथ्वीं ध्यामुतेमां कस्मे देवायहविषा विधेम ॥ This can be translated as follows: "In the beginning was the Divinity in his splendour, manifested as the sole Lord of Creation, and he upheld the earth and the heavens, who is the Deity we shall worship with our offerings." Abinash C Bose, Hymns from the Vedas: Original Text and English Translation with Introduction and Notes (Asia Publishing House, New York, 1966), p 94. The term Hiranyagarvha (हिरण्यगर्भ) means "the golden germ" and it is described in the Rig Veda as having germinated the waters which contain creative force and everything germinal and which produce fire and sacrifice.

46 Norman Stone et al (ed), Harper Collins Atlas of World History (3rd edition) (Borders Press in association with Harper Collins, Ann Arbor, 1998), p 83.

47 Gautam states that: "The Rig Veda Samhita appears to have evolved over many hundreds of years, judging by the style of composition of various Mantras by the Rishis and the historical facts inherent in them." Prasanna C Gautam, Modern English Translation of the Rig Veda Samhitaa (Bharatiya Vidya Bhavan, Mumbai, 2014), Vol I, p xx. 
of a Byasa (or Vedabyasa) was not the work of an individual Rishi, but was rather the collective effort of a group of Rishis or Brahmins working under the supervision and editorship of a principal Byasa.

The Vedas in their current form comprise the editions and divisions created by Krishna Dwaipayan. The four Vedas constitute the core teachings of both Hinduism and Buddhism, and were further expanded in the form of 108 (or so) Upanishads by succeeding generations of sages over a period of several centuries. As noted by Olivelle, the Upanishads shaped "the central religious concepts of both Hinduism and of the new religious movements, such as Buddhism and Jainism that emerged not long after the composition of the Upanishads". ${ }^{48}$ Olivelle adds that: "Upanishads are the Vedic scriptures par excellence of Hinduism." However, neither the Vedas nor the Upanishads were written down as they are in their present form until much later. Instead, for many years, these teachings were passed on to generations of Rishis and Brahmins via oral transmission. The Vedas, the Upanishads and Smritis such as the Manusmriti, were couched in metrical stanzas for the purpose of memorisation, recitation and oral transmission to newer generations. Therefore, in this context, the teachings became known as Smritis - that is, teachings based on memory.

Traditionally, cadres of Brahmins were trained and educated in a Gurukul (a college headed by a Rishi or a senior Brahmin), so that every generation could learn, memorise and recite the Vedas from the gurus of the previous generation, and pass them on to a new generation of Brahmin disciples. There are Hindu families in existence today that have surnames associated with the task of reciting the Vedas and imparting them to the next generation. Examples of these names are Vedi (those whose task it was to memorise one Veda, then pass it on to the next generation); Dwivedi (those who learned two Vedas); Trivedi (for three Vedas); Chaturvedi (for four Vedas); and Suvedi or Subedi, which is a corrupted version of this surname ${ }^{49}$ (those whose task it was to disseminate and explain the message of the Vedas to ordinary people). The job of learning and passing on the Vedas still exists, although numbers

48 Patrick Olivelle, Upanishads (translated from the Original Sanskrit) (Oxford University Press, Oxford, 1996), p xxiii.

49 The surname of the present author, "Suvedi" or "Subedi" (a slightly corrupted version), means "those who mastered the Vedas". This follows a tradition of giving names to people who follow certain professions, as practised in many other Eastern and Western societies. This specific name was given to scholars whose main task was to devote their time to the study of the Vedas; Binu Pokharel, "Who is a Brahmin?" Kantipur, Kathmandu (8 February 2020) (in Nepali); also see Rajendra Subedi et al (ed), Subedi Bansabali (Genealogy) (Subedi Welfare Academy, Kathmandu, 2007) pp 47-50 (in Nepali). 
are dwindling; but there are still various Vedis and/or Sastris alive who can recite the whole of one Veda. It was also often the case that different clans of Brahmins would specialise in learning different parts of the same Veda. For instance, the Subedis (or Suvedis) were supposed to specialise in learning the Madhyandini Sakha (Branch) of the White Yajurveda (Yajurveda, of the three Vedas, has been divided into two parts, known as the Black Yajurveda and the White Yajurveda).

\subsection{Social Mobility during the Vedic Period}

During Vedic times, the status of Brahmin was not viewed as a caste, but their work was viewed as a profession. Anyone born into any family background could become a Brahmin through learning. Furthermore, some of the most famous Rishis of ancient times did not come from a Brahmin background. They attained their Brahmin status via the mastery of Vedic knowledge and their ability to guide society onto a virtuous path. They were the scholars or academics of their time. Krishna Dwaipayan, a famous Byasa, ${ }^{50}$ did not come from Brahmin origins; nor did the distant ancestors of the current author, whose heritage can be traced back to a Rishi known as Bharadwaz, who was one of seven renowned Rishis practising during the Vedic period ${ }^{51}$ and who also came from a non-Brahmin background. Likewise, the famous sage Valmiki, who composed popular Hindu epic the Ramayana, rose to fame from a non-Brahmin background and was given the title the "first poet of Sanskrit", or Valmiki the Great.

Sophisticated knowledge and skills are needed to understand and internalise the messages contained in the four Vedas and in the Upanishads; and in Vedic times, this content was not easily accessible to non-Brahmins. This is because the Vedas and many of the Upanishads were composed by various Rishis over the centuries in ancient Sanskrit, and particularly during the pre-Panini period (ie, before Panini composed the first version of Sanskrit grammar in circa the sixth century BC). Hence, the four Vedas and many Upanishads are not necessarily based on modern Sanskrit grammar, which makes them more difficult to understand for ordinary men and women. Various Puranas and epics were composed by various Byasas in later time periods to make it easier for ordinary people to understand the messages contained in the four Vedas and in the

50 Gautam states that Krishna Dwaipayan was the 28th Byasas; Prasanna C Gautam, Modern English Translation of The Rig Veda Samhitaa (Bharatiya Vidya Bhavan, Mumbai, 2014), Vol I, p xii.

51 Binu Pokharel, "Who is a Brahmin?" Kantipur, Kathmandu (8 February 2020) (in Nepali); Rajendra Subedi et al (ed), Subedi Bansabali (Genealogy) (Subedi Welfare Academy, Kathmandu, 2007), pp 34, 52 (in Nepali). 
Upanishads. ${ }^{52}$ Accordingly, many of these messages are now couched in the vernacular storytelling format, with characters taken from contemporary societies, to facilitate easier learning, understanding, internalisation and practise.

\subsection{Social and Religious Discord in Hinduism and the Rise of Buddhism}

During this process, some deviations from ancient values were incorporated into the Vedas, which the authors - mainly Brahmins - sought to introduce in order to secure their own supremacy vis-à-vis other classes or groups of people in society. Brahmins devised their own creative interpretation of the Vedas and the Upanishads, often inventing new stories, exaggerating elements of existing stories and prescribing rigid and conservative rules for society, and relegating women, non-Brahmins and non-Hindus to inferior status. This created all sorts of problems in society, resulting in disharmony and suffering. Moral decay and corruption became prevalent. It was during this period that Siddhartha Gautam - who later came to be known as Buddha or Gautam Buddha ("the learned or enlightened one") - rose to prominence by reinterpreting existing religious scriptures. Buddha encouraged meditation and contemplation over following the orthodox rituals of worshipping fire, gods and goddesses. In doing so, he challenged the dogmas of the Brahmin prescription of conservative rules, including the rigid division of people into various castes.

Buddha proposed his own philosophy of life based on inner peace, non-violence, equality and egalitarianism. In other words, he was a Rishi who sought to discover the true meaning of the Vedas and the Upanishads, and who offered his own interpretation of the essence of these scriptures for the betterment of humanity. Indeed, Buddhist teaching is based on Siddhartha Gautam's analysis and understanding of these ancient Hindu scriptures.

As stated by Devi Subedi, the main objective of the Upanishads is to seek truth. ${ }^{53}$ Indeed, Radhakrishnan argues that the message in the Upanishads is that truth is within us. ${ }^{54}$ Thus, the essence of the Upanishads is to seek truth and become enlightened. The principal Upanishads seek to expand Vedic knowledge and the Vedic philosophy of life, and as such are referred to as the concluding texts of the Vedas. Their number once exceeded 200,

52 See Bhaktivedanta Swami Prabhupada, Shrimad Bhagavatam (First Canto, Part One) (The Bhaktivedanta Book Trust, Watford, 2006), p 23.

53 Devi P Subedi, Valmiki ra Vyas: Tulanaatmak Anusheelan (A comparative analysis of Valmiki and Vyas) (Swadesh Prakashan, Kathmandu, 2016), p 8 (in Nepali).

54 S Radhakrishnan, The Principal Upanishads (edited with an introduction, text, translation and notes) (Harper Collins Publishers, George Allen \& Unwin, London, 2012), p 49. 
but only 108 have survived and today just ten are frequently referred to in popular Hindu discourse. The Upanishads that have gradually disappeared were more religious in character than philosophical. However, as with the Vedas, the Upanishads are anonymously authored and are most probably the collective effort of a group of Brahmin scholars working under the direction and editorship of a Rishi or Guru in Gurukul; most are pre-Buddhist and were composed in the seventh and eighth centuries BC. As stated by Radhakrishnan, the Upanishads were composed around the time "when man for the first time simultaneously and independently in Greece, China and India questioned the traditional pattern of life"; 55 and one of those men was Buddha. Therefore, the more philosophical Upanishads have since gained wider appeal within and beyond the Hindu-Buddhist world. ${ }^{56}$

\subsection{The Ramayana: Teachings for a Righteous Life}

John Keay explains that, of all the ancient Hindu scriptures, the Ramayana (thought of as a major epic) "is still alive - indeed kicking". ${ }^{57}$ The Ramayana caught the imagination of the people when it was composed by Valmiki Rishi and has become part of folklore across South and Southeast Asia. It still enjoys a high level of popularity in northern India, Nepal, Thailand and in Bali, where a dramatised version of the epic - the Ram Lila - continues to be staged. The Ramayana became popular in much of Asia and in East Iran, and was translated, with various local adaptations, into Chinese, Urdu, Tamil, Singhalese, Vietnamese, Khmer, Bhasha Indonesia, Malayalam, Burmese and Tibetan. Some variations and adaptations of the Ramayana have also found their way into Buddhist literature. Furthermore, stories based on the Ramayana have been published in some European languages, such as English, Dutch, Portuguese, French and Spanish. ${ }^{58}$

The Ramayana centres on the characters of Rama and his wife Sita, and is narrated by a series of exemplary figures from society. The moral of the story is that everyone should aspire to live up to the expectations stipulated in the Ramayana, and that an ideal ruler and an ideal state are embodied in the figure

\footnotetext{
55 Ibid, p 22.
}

56 For instance, the Mughal Prince, Muhamad Dara Shikoh, translated the Upanishads into Persian in around 1656, and then they were translated into Latin by Anquetil Duperron in around 1802, under the title Oupnekhat; ibid, p 21.

57 John Keay, India - A History: From the Earliest Civilisations to the Boom of the Twenty-First Century (Harper Press, London, 2010), p 45.

58 Devi P Subedi, Valmiki ra Vyas: Tulanaatmak Anusheelan (A comparative analysis of Valmiki and Vyas) (Swadesh Prakashan, Kathmandu, 2016), pp 27-28 (in Nepali). 
of Rama and his kingdom. When the exiled Crown Prince Rama returned to the throne, he is said to have ushered in:

[a] dazzling utopia of order, justice and prosperity under his personal rule. The resultant Ramarajya (or ramraj in Hindi, the rule of Rama) quickly became, and is still, the Indian political ideal, invoked by countless dynasts and pledged by countless politicians, secularist as well as Hindu nationalists. ${ }^{59}$

It is believed that the original version of the Ramayana was briefer than that available today. Like other scriptures in Hinduism, the Ramayana seems to have been expanded by successive generations of Brahmins or Rishis to adapt to contemporary society and make it appealing to ordinary people.

\subsection{The Mahabharata: The Story of Right and Wrong}

In John Keay's estimation, the Mahabharata was composed roughly 500 years after the Vedas $^{60}$ and, on analysis, he is probably right. It is the longest and most enduring of the Hindu scriptures, and concerns developments up to, during and in the aftermath of the Great War, also known as the Mahabharata War, which was fought between feuding camps of the ruling classes in the times of antiquity. Some scholars place the date of the war to an earlier period; ${ }^{61}$ but others place it at c $1400 \mathrm{BC}^{62}$ or even later, at about the seventh or eighth centuries BC. It is possible to argue that the later date seems more credible. The significance of the Mahabharata is that it captures the essence of all the Vedas and the Upanishads; also, it was composed for ordinary people, who often lacked the levels of education needed to read and digest the complex ideas set out in the Vedas and the Upanishads. The Mahabharata contains roughly 100000 verses, and, in the words of John Keay, is "something of an epic in itself". ${ }^{63}$ It is made up of 18 volumes or parts or "Parvas", each of which comprises roughly 300-400 pages of poetry, making it the longest of all poems: three times longer than the Bible and eight times longer than the Iliad and the Odyssey combined.$^{64}$ Composing this collection would have been a mammoth task by any modern standards, let alone by the standards of the time it was compiled.

\footnotetext{
59 John Keay, India - A History: From the Earliest Civilisations to the Boom of the Twenty-First Century (Harper Press, London 2010), p 46.

${ }_{60}$ Ibid, $\mathrm{p} 37$.

${ }_{61}$ Estimates vary, but some put the date to 3102 BC.

62 John Keay, India - A History: From the Earliest Civilisations to the Boom of the Twenty-First Century (Harper Press, London, 2010), p 3.

63 Ibid.

64 CG Weeramantry, An Invitation to the Law (Lawman, New Delhi, 1998), p 12.
} 
The Mahabharata offers a detailed description of the rules for human behaviour, ranging from guidance on benevolent statecraft and the duties of righteous kings to the laws of war. Munshi states that the Mahabharata:

is not a mere epic; it is a romance, telling the tale of heroic men and women and of some who were divine; it is a whole literature in itself, containing a code of life, a philosophy of social and ethical relations and speculative thought on human problems that is hard to rival. ${ }^{65}$

This, indeed, is why it is often said that "what is not in this epic is nowhere to be found". Devi Subedi states that through the form of the epic, the composers (the Vedabyasa) wanted to guide society in the future on the basis of lessons learned in the run-up to and during the Great War, ${ }^{66}$ which had resulted in a loss of life of "epic" proportions, as well as the betrayal and violation of the laws of war and other societal norms. Subedi also explains that this epic is about the inner struggle between right and wrong that each human being experiences, and explores the existence of both divine and demonic tendencies in human beings. ${ }^{67}$ According to Prabhupada, the Mahabharata was written to make the teachings of the Vedas and the Upanishads accessible to ordinary men and women who lacked the kind of education needed to read the Vedas and the Upanishads:

The purpose of the Mahabharata is to administer the purpose of the Vedas, and therefore within this Mahabharata the summary Veda of Bhagavad Gita is placed. The less intelligent are more interested in stories than in philosophy, and therefore the philosophy of the Vedas in the form of the Bhagavad-Gita is spoken by the Lord Sri Krishna. The Bhagavad Gita is the essence of all Vedic knowledge. It is the first book of spiritual values, as the Upanishads are. The Vedanta philosophy is the subject matter for study by the spiritual graduates. ${ }^{68}$

Written as an epic, it tells a moral story of what is right and wrong in society by presenting characters who personify good and bad conduct, and who have moral and immoral characteristics. It also offers techniques for overcoming the suffering and grief experienced in life. It is said that there is no topic within the realm of society and human conduct that is not included in it.

${ }_{65}$ KM Munshi, "Foreword", Kamala Subramaniam, Mahabharata (Bharatiya Vidya Bhavan, Bombay, 1977).

66 Devi P Subedi, Valmiki ra Vyas: Tulanaatmak Anusheelan (A comparative analysis of Valmiki and Vyas) (Swadesh Prakashan, Kathmandu, 2016), pp 566-73 (in Nepali).

$67 \quad$ Ibid, pp 568-73.

68 Bhaktivedanta Swami Prabhupada, Shrimad Bhagavatam (The Bhaktivedanta Book Trust, Watford, 2006) p 226. 


\subsection{The Bhagavad Gita: Reorientation of the Vedic Knowledge}

The Bhagavad Gita (also referred to as "Gita") explores the reorientation and expansion of the philosophical aspects of Vedic knowledge. The text is also known as the Gitopanishad, an Upanishad in itself. The Bhagavad Gita literally means "Song of the Lord" or "Divine Song". It is regarded as a distillation of the Rig Veda and various Upanishads. Therefore, it is often referred to as the fifth Veda. It is part of the Mahabharata and deals with the subject matter of the Great War that took place between feuding royal families. It is the essence of Vedic knowledge and, perhaps, the most important of all Hindu scriptures. It is said that if one reads the Bhagavad Gita, one need not read any other Vedic literature; and in this context, it is regarded as the nectar of the Mahabharata. In many respects, it is the Hindu equivalent of the Quran and of the Bible in terms of its spiritual and philosophical scope and significance. However, unlike the Quran and the Bible, the Bhagavad Gita was never fashioned as a religious book; rather, it is thought of as a spiritual book. Gandhi had the following to say about the significance of the Bhagavad Gita:

When doubts haunt me, when disappointments stare me in the face, and I see not one ray of hope on the horizon, I turn to Bhagavad Gita and find a verse to comfort me; and I immediately begin to smile in the midst of overwhelming sorrow. Those who mediate on the Gita will derive fresh joy and new meanings from it every day. ${ }^{69}$

The Bhagavad Gita is indeed a treasure trove of wisdom. Its 700 verses provide a guide to the science of self-realisation. It is a book that explores Eastern philosophies of life, death, duty, karma, dharma and associated themes, though unlike the Puranas, the Bhagavad Gita does not tell religious stories. The Bhagavad Gita is written in a more modern kind of Sanskrit than the classical Sanskrit used for the Vedas, especially the Rig Veda; nonetheless, it is a complex scripture written in eloquent language, which contains highly advanced and sophisticated ideas. The Bhagavad Gita goes beyond the prescription of the rituals and sacrifices as they are described in the Vedas. Just like Buddha, Krishna does not reject the Vedas, but selects the most philosophical aspects of the Vedas for his focus, while rejecting their overt ritualistic and sacrificial aspects.

69 Mohandas K Gandhi, as cited in Bhaktivedanta Swami Prabhupada, Bhagavad-Gita as It Is (The Bhaktivedanta Book Trust, Los Angeles, 1986), back cover page. 


\subsection{The Shrimad Bhagavatam: An Explanation of Vedic Knowledge}

As noted by Prabupada, all Vedic literature is summarised in the Vedanta Sutras; but for further guidance, a commentary on the Vedanta Sutras was composed in the form of the Shrimad Bhagavatam (श्रीमद् भागवतम्). ${ }^{70}$ This text is composed in a more accessible type of Sanskrit and remains the most studied, popular, revered and influential Purana to this day. It is much more elaborate than the Bhagavad Gita and it seeks to show how to put into practice the messages of the Gita. It is considered the most important collection of ancient wisdom found in the Vedas and in the Upanishads; it describes the Creation and explores the many incarnations and adventures of Hindu god Vishnu throughout human history. Thus the Shrimad Bhagavatam is regarded as encapsulating the essence of all spiritual knowledge in Hinduism.

One of the themes running through the Shrimad Bhagavatam is the science and practice of various types of yoga, mainly bhakti-yoga, which should be undertaken as a devotional service to God. The Shrimad Bhagavatam was composed between 800-1000 CE by Vyāsadeva with the objective of popularising the worship of Vishnu. It was the first Purana to be translated into a European language: Maridas Poullé's French translation of a Tamil version of the Shrimad Bhagavatam was published in 1769, and this introduced many Europeans to Hinduism. A Hindi translation of the Shrimad Bhagavatam, based on an 800-year-old Sanskrit text, was published by the Gita Press, Gorakhpur, ${ }^{71}$ and then translated into English by Prabhupada in $1972 .{ }^{72}$

The Shrimad Bhagavatam was composed at a time when traditional Vedic ideas and the influence of their rituals were losing power, and when the people were being told differing stories by various Rishis about the gods, goddesses, demigods and deities, and the values of Hinduism. At the same time, the influence of Buddhism was increasing. Striving to regain the control over spiritual affairs in South Asia, a new generation of Brahmins felt the need to consolidate the essentials of the Hindu scriptures and composed the Shrimad Bhagavatam. Hinduism is a decentralised belief system, one without an authoritative figurehead and without a universally accepted scripture. As such, Hinduism has been facing a multitude of challenges brought about by emerging novel religious and cultural practices, particularly in the modern age. In order to revive people's interest in Vedic ideas and philosophies, the Shrimad Bhagavatam was composed in a style which resonated with ordinary people. It contains stories

70 Bhaktivedanta Swami Prabhupada, Bhagavad-Gita as It Is (The Bhaktivedanta Book Trust, Los Angeles, 1986), p 27.

71 The 93 rd print edition was published in 2018 by Gita Press, Gorakhpur, India.

72 Bhaktivedanta Swami Prabhupada, Shrimad Bhagavatam (The Bhaktivedanta Book Trust, Watford). 
about incidents that occur in ordinary modern life, which people can relate to. The Shrimad Bhagavatam quickly drew the attention of people from all castes, classes and occupations and remains a popular Purana to this day. Hindus still seek to organise and experience the once-in-a-lifetime event of a weeklong Pooja (a Hindu religious ceremony) in order to listen to this particular Purana being recited and explained by a pandit or priest. A pooja is undertaken with much elaboration, chanting and hawan ${ }^{73}$ with a view to achieving nirvana in this life and moksa, or life in heaven, after death.

\subsection{The Manusmriti: The Laws of Manu and the Laws of Life}

The Manusmriti or the Manavasastra, or the Laws of Manu, ${ }^{74}$ is a masterpiece designed to regulate a wide range of personal, family and social behaviours in the life of a Hindu, from birth to death and from dawn to dusk. It was composed around the second century BC. It is perhaps the most elaborate and comprehensive treatise that has been designed to guide governmental activities, as well as the life of the governed. It is partly a codification, reconsolidation and reorientation of already understood knowledge and practices, and it progressively develops old rules around new principles for life that are suitable for contemporary society.

The Manusmriti is regarded as a Dharmasastra in its own right and has had a profound impact on the lives of the Hindu people. It is still a source of reference for Hindus on many questions of personal, family and societal life. Professor Duncan Derrett states that the Manusmriti "constitutes India's greatest achievement in the field of jurisprudence". ${ }^{75} \mathrm{He}$ goes on to say that it is "one of the world's premier compositions in ancient law, more valuable in every sense than Hammurabi and able to hold its own in comparison to the covenant and priestly codes of Moses" ${ }^{76}$ Furthermore, Doniger explains that it is, "in sum, an encompassing representation of life in the world - how it is,

73 "Havan" or "Homa" is a Sanskrit word for "ritual", whereby an oblation or religious offering is made into a fire. It is rooted in Vedic rituals undertaken from the time of the Rig Veda onwards, and it was also adopted in ancient times by the Buddhist and Jainist movements. It is practised in countries with mainly Hindu-Buddhist-Jain populations in South Asia, Central Asia, East Asia and Southeast Asia; and also by the Hindu diaspora communities of Western countries.

74 For an English translation of Manusmriti, see Wendy Doniger, The Laws of Manu (Penguin Books, London, 1991).

75 JDM Derrett, Manusastravivarna, 2 vols (Franz Steiner Verlag, Wiesbaden, 1975), Introduction, as cited in Wendy Doniger, The Laws of Manu (Penguin Books, London, 1991), p xix.

76 Ibid. 
and how it should be lived". ${ }^{77}$ It has remained a living treatise for a significant amount of time and it formed part of the judicial system in India before and during the Raj. It also seems to have been used as a source of reference when Nepal enacted its first Napoleonic code: the General Code, also known as Muluki Ain. It is still a major source of reference and is recommended reading for law students in many parts of the Hindu world.

Like many Hindu and Buddhist scriptures, the Manusmriti was composed by a dedicated group of learned men who, at the time it was written, worked under the leadership or editorship of Manu (a Rishi). Over the centuries, it has been revised by successive generations of scholars, thereby maintaining the Manusmriti's status as the foremost guide for society. Indeed, rulers have relied on it to govern their countries and it offers people the chance to understand how they can expect their state to treat them. Law making in Hindu states, societies and communities has been guided by the Manusmriti text - so much so that even the British used it to govern Hindu communities in India during the time of the Raj. The Manusmriti also offers guidance for domestic situations such as marriage, divorce, inheritance, partition, guardianship, adoption and stridhan (women's property rights) which has been enacted as law in India and Nepal. The Manusmriti has also gained wider appeal and generated interest further afield outside India. It was one of the first Hindu scriptures to be translated from Sanskrit into European languages - the earliest being a translation into English (published in Calcutta in 1794) ${ }^{78}$ by Sir William Jones, who helped to found the philosophies of modern Indology. As a way of honouring him, a statute depicting Jones holding a volume of the Manusmriti in his hand has been erected in St Paul's Cathedral in London. The Manusmriti has also been translated into other European languages, including German, French, Russian and Portuguese.

The Manusmriti invokes the Dharmasastras and the Nitisastras as the basis for its prescription, but many of its provisions - especially those concerning the caste system - seem to be deviations from the values of the Vedas and the Upanishads. It contains orthodox Hindu rules for all aspects of social life. Under the Manusmriti, the caste system was developed, institutionalised and defined in a more rigid manner. The Brahmins, and especially the Srotriya Brahmins, enjoyed a much more privileged status under the system prescribed in this text. Additionally, although it provided property rights for women, it relegated women to a lower status generally, and contained provisions that

77 Wendy Doniger, The Laws of Manu (Penguin Books, London, 1991), p xvii.

78 Sir William Jones, Institutions of Hindu: The Ordinances of Menu (3rd edition by Standish Grove Grady) (Allen \& Co, London, 1869). 
worked to discriminate against people of the third and fourth castes on issues relating to sentencing and other matters of social interaction.

\subsection{The Arthashastra: The Work of a Genius on Statecraft}

The Arthashastra was compiled by Vishnugupta, who was popularly known as Kautilya and Chanakya. He served as chancellor to the Emperor Chandragupta Maurya around the second and third centuries AD. The Arthashastra is primarily a book about governance and statecraft. It is not regarded as a religious scripture and does not qualify as a Dharmasastra; but it invokes the Dharmasastras and the Nitisastras as a basis for rule, especially concerning personal or private law matters. Its scope is wider than that of the Manusmriti.

The Arthashastra (translated as "The Science of Politics") is an extraordinarily detailed manual of statecraft, comprising 15 books or chapters covering a wide range of topics, ranging from the science of economics to the duties of a king, a code of law and the conduct of foreign policy. ${ }^{79}$ It is essentially a treatise on the art of government, including secret and occult means, intended for practitioners of statecraft. The code of law and justice included in it covers in great detail matters pertaining to both civil and criminal law, including a penal code. However, in relation to criminal and civil matters and the administration of justice, the Manusmriti and the Arthashastra include similar provisions.

Both the Manusmriti and the Arthashastra developed, institutionalised and defined the caste system in a more rigid manner. The Brahmins, especially the Srotriya Brahmins, enjoyed a much more privileged status under the systems prescribed in these texts; so much so that under the Manusmriti and the Arthashastra, the Purohita - the king's chaplain, adviser and preceptor occupied a position next to the immediate royal family and was entitled to the same amount of annual salary as the queen, the crown prince and the queen mother. Like the Manusmriti, the Arthashastra also provides for rights to property for women, but overall, it gives women a lower status in society. It also contains provisions that discriminate against the people belonging to the third and fourth castes on issues relating to sentencing and other matters of social interaction. Yet, it also emphasises the importance of personal liberty of both men and women. For instance, it provides that: "[Even] a prostitute shall not be enjoyed against her will." 80 In a similar way to the Manusmriti, the Arthashastra suggests rules pertaining to all aspects of personal, family and social life, including rules on inheritance, and the partition of ancestral

79 LN Rangarajan, Kautilya: The Arthasastra (edited, rearranged, translated and introduced) (Penguin Books, New Delhi/London, 1992).

$80 \quad$ Ibid, p 483. 
property. It also includes a major section on property law and the protection of stridhan (women's property) which is to be enjoyed by her alone, according to her own free will.

Like the Manusmriti, the Arthashastra has been translated into many languages, including German, Italian and Russian, and it helped to revive interest in Hindu political thinking in Europe. Kautilya was a contemporary of Aristotle, and many European scholars were interested in learning how Kautilya had managed to compile such a comprehensive and complex treatise on the art of governance. There are some similarities between the Arthashastra and Plato's classic work, The Laws, ${ }^{81}$ in the sense that both treatises prescribe detailed rules that cover many different areas of human activity and rules needed to maintain an orderly society. Plato was inspired by his teacher, Socrates, while Aristotle was inspired by his teacher, Plato. However, it is intriguing that both The Laws of Plato and the Arthashastra of Kautilya (written in two different parts of the world in the times of antiquity, and each based on a distinct heritage, Western and Eastern) should have so many similarities in terms of their aims, objectives and content, to a certain extent.

\section{THE ORIGINS, INSPIRATION AND INFLUENCE OF BUDDHIST TEACHINGS}

Buddhism is a philosophy built around gentleness, compassion and achieving inner bliss (a state known as nirvana). ${ }^{82}$ It is basically an offshoot of Hinduism and it increased in popularity when orthodox Hinduism was experiencing a turbulent time. Concerned by the misery suffered by other people, Siddhartha Gautam (a prince from a Hindu principality in modern-day Nepal) decided to embark upon a quest to attain inner harmony and promote peace, equality and happiness between all human beings. He spent much of his early life as a scholar and thinker, and the majority of the material available to him would have been the traditional Hindu scriptures, including the Vedas and the Upanishads. He was born in an age when thinkers and philosophers began to question perceived wisdom, old dogmas and traditional patterns of life. Many people sought to explore new ideas in an attempt to usher the world into a new era for the betterment of humanity.

81 Trevor J Saunders (translated with an introduction), Plato: The Laws (Penguin Books, Middlesex/New York, 1975).

82 See on Buddhism and international law generally, KN Jayatilleke, The Principles of International Law in Buddhist Doctrine, Academie de droit international, Recueil Des Cours, 1967-I, Tome 120 de la collection, pp 445-556; CG Weeramantry, "Buddhism and humanitarian law", in VS Mani (ed), Handbook of International Humanitarian Law in South Asia (Oxford University Press, New Delhi, 2007), pp 3-13. 
In the words of Derrett, Buddhism is "a reformed and systematised Hindu faith accompanied by advanced social ideas". ${ }^{83}$ For instance, Buddhist cosmology includes the Hindu notions of heaven and hell, and it foregrounds the significance of Mount Meru in the same way that the Hindu scriptures do. ${ }^{84}$ Furthermore, references to the three Vedas (the Rig, Sama and Yajur) are apparent in early Buddhist literature ${ }^{85}$ as well as references to the Brahmins as people who are versed in the Vedas. This suggests that Buddha was seeking "truth" before the fourth Veda, the Atharva Veda, was composed. Buddhism represents the continuation of Vedic knowledge in a modernised or reformed form, designed to suit the needs of the new era in which it was written.

The three Vedas and most of the early principal Upanishads expound on different philosophies of life, and this information was available to Buddha when he sought alternative ideas to guide his contemporary society. However, after reading and digesting these Hindu scriptures, he remained unsatisfied and thus embarked upon a journey to discover ideas that might enhance the positive elements that existed in these old scriptures, rejecting what he felt were the negative elements, such as sacrificial rituals, the caste system and idol worship. He seems to have experienced the teachings of all the major Hindu teachers of his day, attending one ashram after another, seeking to interact with Hindu teachers, Rishis and ascetics in his quest to achieve nirvana. He also experimented with different forms of yoga, lived an extremely austere life and eventually concluded that the Middle Path was the best. Unlike many of the Rishis he met, he was not interested in exploring how to get to heaven, but rather how to find release from samsarik (worldly sufferings and worry) on earth, including worry about the cycle of death and birth. He had a highly inquisitive mind and was not satisfied with the knowledge imparted by the Vedas and the Upanishads alone.

By the time Buddha developed his ideas, the Upanishads were already in the process of reform away from idol-worshipping and from the more ritualistic or sacrificial or Brahministic aspects of the Vedas. Buddha decided to accelerate these reforms by breaking new ground. For instance, the Upanishads had the following to say about rejecting idol worship: "The vulgar look for their gods in water, men of wider knowledge in celestial bodies, the ignorant in (images

$83 \mathrm{~J}$ Duncan M Derrett, Religion, Law and the State in India (Oxford University Press, Delhi, 1999), p 28.

${ }^{84}$ Jana Igunma, "Introduction" in Jana Igunma and San San May (eds), Buddhism: Origins, Traditions and Contemporary Life (British Library, London, 2019), p 17.

${ }_{85}$ Sutta Nipata 1019, as cited in S Radhakrishnan, The Principal Upanishads (edited with an introduction, text, translation and notes) (Harper Collins Publishers, George Allen \& Unwin, London, 2012), p 44. 
made of) wood or stone but the wise see the Supreme in their own self." ${ }^{\prime \prime 6}$ Upanishads such as the Svetasvatara Upanishad were "an attempt to reconcile the different philosophical and religious views which prevailed at the time of [their] composition". ${ }^{87}$ However, plurality of thought was already present at the time and, drawing on these advancements, Buddha championed the idea that hell and heaven were already here on earth, and were the result of karma experienced in the present life. Radhakrishnan explains that "alienation from our true nature is hell, and union with it is heaven". ${ }^{88}$ Buddha pioneered this idea in his teachings.

Buddha reoriented messages contained in the Vedas and in the Upanishads, and he composed a Veda (and new Upanishads) that conveyed his new ideas and beliefs. Ultimately, he was a kind of Vedabyasa, who aimed to bring about fundamental change in a person's outlook to life. Like Krishna, Buddha went beyond the orthodoxy of the Vedas. However, he did not discard Hindu values (Vedic values) in their entirety. Instead, he sought alternative ideas for bringing about inner harmony, peace, equality and happiness to all human beings. He studied, meditated and contemplated for a long time before reaching conclusions that he used to set up a new belief system, and his disciples are still committed to achieving nirvana and enlightenment today by following the path shown by him.

\subsection{The Core of the Buddhist Scriptures}

The Buddhist Tripitaka is regarded as the oldest collection of Buddhist scriptures and comprises three major parts: the Sutra Pitaka (discourses attributed to the historical Buddha), the Vinaya Pitaka (monastic disciplines) and the Abhidharma Pitaka (the higher teachings). ${ }^{89}$ Buddha's teachings to ordinary people are explained in very simple terms: refrain from killing, stealing, sexual misconduct and consuming intoxicants. ${ }^{90}$ Buddha - who is also referred to as the enlightened or awakened one - explained complex emerging ideas derived from the principal Upanishads in an accessible language for consumption by

86 S Radhakrishnan, The Principal Upanishads (edited with an introduction, text, translation and notes) (Harper Collins Publishers, George Allen \& Unwin, London, 2012), p 140 .

${ }^{87}$ Ibid, $\mathrm{p} 707$.

88 Ibid, $\mathrm{p} 95$.

89 Jana Igunma, "Introduction" in Jana Igunma and San San May (eds), Buddhism: Origins, Traditions and Contemporary Life (British Library, London, 2019), p 17.

90 Dion Peoples, "Buddhist Practice: Mindfulness and Compassion", in Jana Igunma and San San May (eds), Buddhism: Origins, Traditions and Contemporary Life (British Library, London, 2019), p 182. 
ordinary people who lacked the sophisticated skills of understanding possessed by Brahmins. However, Buddha rejected idol worship and many other Hindu rituals that had benefited the Brahmins. This led the Brahmins to criticise him, mainly because they were denied a monopoly over the religious scriptures; Buddha was labelled an atheist and criticised in Hindu scriptures such as the Ramayana. A centuries-long philosophical struggle began between Buddhists and Brahmins as the latter attempted to regain control and preserve their power base. This is one reason why Buddha has been referred to as a "Protestant" against the religion of his country in some Western literature. ${ }^{91}$

Buddha, the philosopher, was guided by some of the Upanishads that were already in existence, and himself composed a new "Upanishad" containing new ideas or belief systems after he achieved nirvana. His ideas influenced other Upanishads composed after his life. Indeed, Radhakrishnan explains that Upanishads such as the Maitri Upanishad reflect the influence of Buddhist thoughts. ${ }^{92}$ According to Edmond Holmes, it was Buddha who expanded the teachings of the Upanishads by elaborating the general ideal of self-realisation into a comprehensive scheme of life. ${ }^{93}$ Holmes goes on to add:

In the West the idea is still prevalent that Buddha broke away completely from the spiritual idealism of the Upanishads; that he denied God, denied the soul, and held out to his followers the prospect of annihilation as the final reward of a righteous life. This singular misconception, which is not entirely confined to the West, is due to Buddha's agnostic silence having been mistaken for comprehensive denial. It is time that this mistake was corrected. It is only affiliating the ethics of Buddhism to the metaphysics of the Upanishads that we can pass behind the silence of Buddha and get into touch with the philosophical ideas which ruled his mind, ideas which were not the less real or effective because he deliberately held them in reserve. ${ }^{94}$

91 See, for example, The Prospective Review of 1850, The Christian Remembrancer of 1858 and The Journal of Sacred Literature of the 1860s: see in SN Balagangadhara, The Heathen in his Blindness... Asia, the West, and the Dynamic of Religion (EJ Brill, Leiden/New York, 1994), pp 143-144.

92 S Radhakrishnan, The Principal Upanishads (edited with an introduction, text, translation and notes) (Harper Collins Publishers, George Allen \& Unwin, London, 2012), p 793.

93 Edmond Holmes, "An Introduction", in S Radhakrishnan, The Principal Upanishads (edited with an introduction, text, translation and notes) (Harper Collins Publishers, George Allen \& Unwin, London, 2012), p 948.

$94 \quad$ Ibid, pp 948-949. 
Both Holmes and Radhakrishnan are united in their desire to establish the connection between Hinduism and Buddhism. Radhakrishnan expresses this connection in the following words:

The only metaphysics that can justify Buddha's ethical discipline is the metaphysics underlying the Upanishads ... Buddhism helped to democratize the philosophy of the Upanishads, which was till then confined to a select few. The process demanded that the deep philosophical truths which cannot be made clear to the masses of men should for practical purposes be ignored. It was Buddha's mission to accept the idealism of the Upanishads at its best and make it available for the daily needs of mankind. Historical Buddhism means the spread of the Upanishad doctrines among the people. It thus helped to create a heritage which is living to the present day. ${ }^{95}$

The new belief system developed by Buddha was based on non-violence, inner peace and the equality and personal liberty of all human beings. This is how Buddha came to be known as Gautam Buddha, the learned and the enlightened. He was a first-rate Mahatma who sought to reform Vedic values by propounding new values and reorienting the existing philosophical ideas of Upanishads that advocated egalitarianism and tolerance, and that became part of the values of sanatana dharma (the Eternal Law or Universal Moral Code), which can be found in both Hinduism and Buddhism still in practice today. As stated by Prabhupada: "Sanatana dharma does not refer to any sectarian process of religion." 96 The word "sanatana" means "that which has neither beginning nor end". ${ }^{97}$ Prabhupada adds the following:

The English word "religion" is a little different from sanatana dharma. Religion conveys the idea of faith, and faith may change. One may have faith in a particular process, and he may change this faith and adopt another, but sanatana dharma refers to that activity which cannot be changed. For instance, liquidity cannot be taken from water, nor can heat be taken from fire. Similarly, the eternal function of the eternal living entity cannot be taken from the living entity. Sanatana-dharma is eternally integral with the living entity ... Non-sanatana religious faith may have some beginning in the annals of human history, but there is no beginning to the history of sanatana dharma because it remains eternally with the living entities. ${ }^{98}$

Prabhupada goes on to explain why sanatana dharma has no end or beginning, and exists everywhere that human beings exist as part of a society or in nature.

\footnotetext{
Ibid, p 949.

96 Bhaktivedanta Swami Prabhupada, Bhagavad-Gita as It Is (The Bhaktivedanta

Book Trust, Los Angeles, 1986), p 18.

${ }_{97}$ Sripada Ramanujacarya, as cited in ibid, p 18.

$98 \quad$ Ibid, p 18.
} 
This is because human beings have a duty or dharma towards nature and should not undertake any activity that unduly and adversely affects nature:

No living being is exempt from rendering service to other living beings, and, therefore, we can safely conclude that service is the constant companion of the living being and that the rendering of service is the eternal religion of the living being. Yet man professes to belong to a particular type of faith with reference to particular time and circumstance and thus claims to be a Hindu, Muslim, Christian, Buddhist, or any other sect. Such designations are non-sanatana-dharma. A Hindu may change his faith to become a Muslim, or a Muslim may change his faith to become a Hindu, or a Christian may change his faith and so on. But in all circumstances the change of religious faith does not affect the eternal occupation of rendering service to others. The Hindu, Muslim or Christian in all circumstances is servant of someone. Thus, to profess a particular type of sect is not to profess one's sanatana-dharma. The rendering of service is sanatana dharma. ${ }^{99}$

The theory of sanatana dharma conveys the idea that human rights are inherent in human beings simply by the state of being human. Such rights are not granted and cannot be taken away from human beings. Indeed, such rights can only be described, declared or acknowledged, or guaranteed or stipulated in a legal instrument.

\subsection{The Essence of the Buddhist Middle Path}

The mission of Buddha was to democratise, simplify and popularise the values found in the Vedas and the Upanishads for the rank and file of mankind. His theories of the Middle Way or the Middle Path (between the extremes of indulgence and asceticism), the Noble Eightfold Path, the Wheel of Dharma and the Three Refuges sought to provide a code for the path of human life. These aims are summed up by Freeman and Shearer as follows:

To get to the roots of our mind, for our life is but the extension of our thinking and feeling and the goal of real happiness, we all seek what lies deep within ourselves, not in endless manipulation, or even experience, of the outside world. The tool for this exploration is meditation, which establishes a basis of inner silence, from which the mind can see calmly and clearly, unclouded by fear, expectation or projection. Any other approach to the problems of life is ultimately only cosmetic - like the gardener who tries to nourish a wilting plant by polishing its leaves. The intelligent approach is to water the root, and the whole plant will naturally flourish. As awareness of reality grows, there is no abandoning of those who are suffering; on the contrary, insight must be accompanied by loving kindness, the mind balanced by the heart.

Ibid, p 19. 
According to Dhammasami, the teachings of Buddha mean that every individual must understand the following four noble truths:

That suffering exits, and it is universal. However, much of the suffering experienced by humans, such as anger, is an option or choice, and human beings can elect to avoid it.

The causes of suffering result from personalisation and clinging to suffering, and by not viewing it as a universal truth.

An end to suffering. Observing suffering and its causes can contribute to bringing an end to suffering.

The way to bring an end to suffering. One can bring an end to suffering by following the Middle Path. By following this Middle Path, it is possible to observe and examine suffering, discover the causes of suffering, and, thereby, remove them. The eight principles for following the Middle Path are adopting: (a) the right view; (b) the right emotions/right intentions; (c) the right speech; (d) the right actions; (e) the right livelihood; (f) the right effort; (g) the right mindfulness; and (h) the right concentration.

The above examples show that emphasis is placed on the self-training of the mind, which is undertaken directly in various meditation practices. ${ }^{100}$ This message is shared by the Rig Veda and other Hindu scriptures, including the Bhagavad Gita. The message is that one must be enlightened and know one's soul in order to deal with suffering and achieve liberation and a blissful life. ${ }^{101}$ Keay explains that Buddha's teachings concern ways of overcoming human suffering and achieving release from suffering through moral regeneration: "Suffering came from within, from desire and indulgence. By mastering desire, restraining indulgence and yet eschewing extreme asceticism, the human condition became bearable, and merit might be accumulated whereby release (nirvana) might eventually be attained." 102 Keay further explains that:

The notion of continuous rebirths and the challenge of escaping from their endless cycle were common to both orthodox teachings derived from the Upanishads and the to the Buddha's teaching. Buddhism was not a belief system, not a rival faith to the post-Vedic cults which prevailed under Brahmanical direction, but more a complementary discipline. About gods, worship, offerings, prayers, priests, and ritual, the Buddha claimed no special knowledge. He offered merely heightened insight, not divine revelation. It was his followers in the generations to come who would

100 Khammai Dhammasami, "Wheel of Life: Philosophy and Ethics" in Jana Igunma and San San May (ed), Buddhism: Origins, Traditions and Contemporary Life (British Library, London, 2019), pp 75, 94-95, 100 and 103. See also, Dion Peoples, "Buddhist Practice: Mindfulness and Compassion", ibid pp $165 \mathrm{ff}$.

101 Devi P Subedi, Valmiki ra Vyas: Tulanaatmak Anusheelan (A comparative analysis of Valmiki and Vyas) (Swadesh Prakashan, Kathmandu, 2016), p 162 (in Nepali).

102 John Keay, India - A History: From the Earliest Civilisations to the Boom of the Twenty-First Century (Harper Press, London, 2010), p 66. 
elevate the Buddha and other semi-enlightened ones (Bodhisattvas) into deities, thus claiming for Buddhism the authority and supernatural paraphernalia of a religion. ${ }^{103}$

The core of Buddha's teachings or dhamma ${ }^{104}$ (which is a Prakrit spelling of the Hindu word dharma) places emphasis on non-violence, on preserving life in all its forms and on the "right conduct" towards one's fellow human beings. ${ }^{105}$ These teachings revolve around the five virtues of human life: compassion, charity, generosity, purity and truthfulness. The ultimate aim of life in both Buddhism and Hinduism is the liberation of the soul known to achieve nirvana in the former and moksa in the latter, but the process of achieving these two things is similar in both belief systems. As noted by Sarao, "the Buddhist Pañcasīla (Five Virtues) embodies recognition of both the right to life and the right to property", and Buddhism upholds that all human beings are born with complete freedom and responsibility and that, from a Buddhist perspective, "one is indeed one's own lord (attā hi attano nātho)". ${ }^{106}$ When citing Buddhist scriptures, Sarao adds the following:

Buddhism sees all human beings as equal in dignity and rights irrespective of considerations such as caste, race, colour, creed, and gender etc ... Placing man and woman on the same pedestal, Buddhism does not recognize rights and freedoms for the male which cannot be extended to the female. Indeed, as borne out by the Therīgāthā, women actually enjoyed a high degree of intellectual freedom under Buddhism, being able thereby to gain spiritual advancement on an equal basis. The Buddha clearly held the view that one's sex, like one's caste, presented no barrier to attaining the Buddhist goal of liberation. ${ }^{107}$

Thus, the idea of human rights exists in both Buddhism ${ }^{108}$ and Hinduism, albeit in the context of dhamma or dharma. Buddhism prescribes teachings not only

\section{Ibid.}

104 As stated by Keay, the Buddhist idea of dhamma is a concept like the Hindu dharma and is difficult to translate, but is "imbued with positive and idealised connotations in both orthodox Vedic literature and in the heterodox doctrines of Buddhists, Jains, and Ajivikas. Invoking a natural order within which all manner of creation had its place and its role, it was something to which no one, be he Brahmin or Buddhist, emperor or slave, could reasonably take exception". John Keay, India - A History: From the Earliest Civilisations to the Boom of the Twenty-First Century (Harper Press, London, 2010), p 98.

105 Ibid, p 96.

106 Karam Tej Sarao, "Human Rights in Buddhism" (2017), www.researchgate.net/ publication/315863913_Human_Rights_in_Buddhism/.

107 Ibid.

108 Sallie B King, "Buddhism and Human Rights" in John Witte and M Christian Green (eds), Religion and Human Rights: An Introduction (Oxford University Press, Oxford, 2011), ch 6. 
for the citizenry, but also for rulers; they too had to observe Buddhist principles when they ruled. In this respect, the following duties should be undertaken by kings:

The first of the Ten Duties of the King is liberality, generosity, and charity (dana). The second is having a high moral character (sila).

The third is sacrificing everything for the good of the people (paricaga).

The fourth is honesty and integrity (ajjava).

The fifth is kindness and gentleness (maddava).

The sixth is austerity in habits (tapa).

The seventh is freedom from hatred, ill-will, and enmity (akkodha).

The eighth is non-violence (ahimsa).

The ninth is patience, forbearance, tolerance, and understanding (khanti).

The tenth is non-opposition, and non-obstruction (avirodha), i.e., he should rule in harmony with his people. ${ }^{109}$

These values of Buddhism seem to have inspired generations of rulers within and beyond South Asia, including China and Japan. As stated by Vincent Smith, the Buddhist principles of government and tolerance of other religions and peoples reached heights seldom matched in history during the latter part of the reign of Emperor Ashok in India. ${ }^{110}$

\subsection{The Integration of Buddhism into Hinduism}

The popularity of Buddhist teachings and other similar ideas, such as the Jain code of conduct, posed challenges to the ritualistic and sacrificial aspects of Vedic values and to the authority of the Brahmins. In response, the Brahmins decided to try to integrate Buddhism into Hinduism and began to fashion Buddha as an incarnation of the Hindu god Vishnu. Thus, there is mention of Buddha as the ninth incarnation of Vishnu in the Shrimad Bhagavatam, ${ }^{11}$ which is classed as the main Hindu Purana, also known as the Purana of Puranas. This realisation was not a half-hearted attempt, because there are many concepts shared by both Hinduism and Buddhism. According to Prabhupada, the purpose of this integration was to revive people's faith in Hinduism and in the Vedic philosophies via Buddhism, and to preserve Vedic

109 Walpola Rahula, What the Buddha Taught (The Gordon Fraser Gallery Limited, Bedford, 1959), pp 84-86, as cited in CG Weeramantry, An Invitation to the Law (Lawman, New Delhi, 1998), p 248.

110 Vincent A Smith (translator and editor), The Edicts of Asoka (Essex House Press, London, 1909), as cited in CG Weeramantry, An Invitation to the Law (Lawman, New Delhi, 1998), p 249.

111 Shrimad Bhagavatam, 1.3.24; see Bhaktivedanta Swami Prabhupada, Shrimad Bhagavatam (The Bhaktivedanta Book Trust, Watford, 2006), pp 168-171. 
values. There are also many elements in common between the teachings of Buddha and Krishna: for example, the Middle Way, various forms of yoga and meditation. Igunma notes that the core values of Buddhism - the Middle Way and the promotion of awareness, compassion, tolerance and non-violence - shape the three main schools of Mahayana (mainly in the East and parts of Southeast Asia), Theravada (mainly in parts of South and Southeast Asia) and Vajryayana (mainly in Central Asia); and these values also "fostered the integration of religious elements that originated in Hinduism, ancestor worship and other pre-Buddhist faiths". ${ }^{112}$ Indeed, the second-oldest university in the world - after the first university of Taxasheela, in modern-day Punjab - was established in Nalanda, in Bihar, to teach Buddhism as well as other Hindu philosophies and beliefs, and functioned between the fifth and thirteenth centuries. ${ }^{113}$

\subsection{Buddha and Krishna: The Modernisers of Hinduism}

The later editions of the two most famous Hindu epics - the Ramayana and the Mahabharata - were composed around the time Buddha had achieved enlightenment, about $500 \mathrm{BC}$. There are many similarities between the Bhagavad Gita and Buddhist Dhammapada teachings. Indeed, the philosophies that underpinned both of these works were similar, and both were inspired by the Vedas and the Upanishads. Furthermore, both works advocate the liberation of the soul or nirvana and the release from worldly sufferings through different forms of yoga. It is believed that the Dhammapada's verses were spoken by Buddha on various occasions and written down later by his followers. The emphasis on personal liberty is stronger in Buddhism than it is in most Hindu scriptures. The focus of Buddha's teachings was to enable human beings to overcome their suffering though their own actions and thoughts. For instance, Buddha explains the following:

All that we are is the result of what we have thought: it is founded on our thoughts; it is made up of our thoughts. If a man speaks or acts with an evil thought, pain follows him, as the wheel follows the foot of the ox that draws the carriage. ${ }^{114}$

112 Jana Igunma, "Introduction”, in Jana Igunma and San San May (eds), Buddhism: Origins, Traditions and Contemporary Life (British Library, London, 2019), p 9.

113 History and Revival of Nalanda University, https://nalandauniv.edu.in/about -nalanda/history-and-revival.

114 Max F Müller, The Dhammapada (Sacred Books of the East, Vol X) (Oxford University Press, Oxford, 1881), Ch I, Twin Verses (Yamaka-vaggo). 
According to Devi Subedi, the Buddhist scripture, the Dhammapada, and the Bhagavad Gita share many similar verses, and include verses relating to the qualities needed to be a Brahmin. ${ }^{115}$ This is why attempts were made to combine Buddhism and Hinduism, and to regard both Krishna and Buddha as incarnations of the Hindu god Vishnu. It was perhaps as a result of these attempts that non-violence became part of Hindu thought and people stopped the sacrifice of animals at some Hindu festivals, especially the festivals observed by the followers of the Shaiva and Vaishnav sects. Thus, there was a unity of purpose and complementary spirit between these two offshoots, which sought to nourish both the spirituality and the personal liberty of the individual. It was only in later periods that puritan Brahmins began to oppose Buddhism - mainly because it challenged their supremacy in society, and especially because it rejected idol worship and many of the more rigid Hindu rituals, such as animal sacrifices. The Brahmins had promoted rigid hierarchy and discriminatory beliefs and practices within Hinduism, and this Brahmin orthodoxy resulted in Buddhism becoming popular among the masses; it spread rapidly throughout Asia, all the way to China, Japan, Korea and Vietnam.

The Bhagavad Gita was not part of the original Mahabharata composed some 500 years earlier, but was added later to the canon of the Mahabharata. It was composed during the transition period from the Vedic era to the Puranic era. According to Devi Subedi, some of the teachings of the Bhagavad Gita seem to have been influenced by the teachings of Buddha. ${ }^{116}$ At this time, two strands of thought (Brahministic Hinduism and pacifist Buddhism) were competing for influence and Buddhism was winning the day. This is why the Bhagavad Gita was composed: to change the course of Hinduism away from puritanism and towards more a philosophical outlook, which can be found in the Vedas, in the Upanishads and in Buddhist teachings. Using the Bhagavad Gita, the Vedabyasa wanted to win back people who had been impressed by the teachings of Buddha and who were embracing Buddhism in significant numbers.

The Bhagavad Gita was a reformist scripture that sought to include the essence of the Vedas, the Upanishads and some elements of Buddhism, and to be more appealing to the people. This was a successful goal and remains so to this day. This philosophy discourages people from idol worship and from animal sacrifice, and teaches about universal values of humanity and ideas of

115 Devi P Subedi, Valmiki ra Vyas: Tulanaatmak Anusheelan (A comparative analysis of Valmiki and Vyas) (Swadesh Prakashan, Kathmandu, 2016), pp 377-379 (in Nepali).

116 Ibid, p 192 (in Nepali). 
right and wrong. It also encourages people to practise various forms of meditation to overcome suffering, just as Buddhism does.

\subsection{The Influence of Buddhist Teachings in China}

The teachings of Buddha were not confined to India and Nepal or South Asia. They spread as far west as Afghanistan and then to China, Japan and other states in the Far East. Originally, the teachings spread to China from Central Asia, via the Silk Road or the Silk Route that had been opened up by China for the purpose of trading with European countries in the second century BC. Once introduced into China, Buddhism spread rapidly within the country and became the official state religion in $379 \mathrm{CE}$. As stated by President Xi of China, "More than 1,600 years ago, the Chinese and Nepali monks Fa Hien and Buddhabhadra visited each other's country and together translated Buddhist scriptures into Chinese." 117 This is how Buddhism brought its values to China and connected the Indian civilisation with the Chinese civilisation. According to a white paper produced by the government of China, Buddhism has a 2000-year-old history in China. Today, there are more than 13000 Buddhist monasteries in China and about 200000 monks and nuns, including about 120000 Tibetan lamas and nuns, and more than 3000 monasteries. ${ }^{118}$

Although China and India are populous nations inhabited by people of different races, languages and civilisations, they are connected in terms of their spiritual heritage. The linchpin is Buddha, who was born in Lumbini, in modern-day Nepal. Known as तपोभूमि (land of meditation and contemplation) and ज्ञानभूमि (land of spiritual knowledge) in the Hindu and Buddhist pantheon, Nepal has traditionally served as a bridge between the two major civilisations of the East. ${ }^{119}$

Furthermore, ideas in Hinduism about heaven and hell and birth and rebirth also exist in Buddhism. Likewise, the sacred Mount Meru as described in Hindu scriptures finds its description in Buddhist scriptures also; and some of the verses in Buddhist scriptures resonate with those in the Upanishads. For

117 Xi Jinping, President of the People's Republic of China, "Toward Greater Progress of China-Nepal Friendship across the Himalayas", China Daily: www.chinadaily.com.cn/a/201910/11/WS5da026bba310cf3e3556ff60.html.

118 'China's freedom of religious belief', www.gov.cn/zhengce/2005-05/26/content 2615747.htm/; this was translated for the present author by a Chinese scholar at the University of Leeds (it is on file).

119 Khammai Dhammasami, "Wheel of Life: Philosophy and Ethics" in Jana Igunma and San San May (eds), Buddhism: Origins, Traditions and Contemporary Life (British Library, London, 2019), pp 78-79. 
instance, the Brihadaranyaka Upanishad ${ }^{120}$ states that the Self is his or her own light (आत्मैवस्य ज्योतिर भबति) ${ }^{121}$ and Buddha advises his disciple, Ananda, "to be a light unto yourself ..." 122 The emphasis in both Hinduism and Buddhism is on regarding the inner soul of the individual as the source of happiness and enlightenment. There are some other similarities between Buddhist scriptures and the Bhagavad Gita: for example, the sensual sphere (kama-dhatu), the form sphere (rupa-dhatu) and the formless sphere (arupa-dhatu) (the latter two are determined by the attainment of meditative absorption - jhana) ${ }^{123}$ are described in Buddhist scriptures, and are similar to teachings about the nature of human beings as described in the Bhagavad Gita.

Buddhism was introduced to China initially by Chinese monks, who visited Buddhist holy sites in north India on pilgrimage, and by Chinese scholars. One such monk was Fa Hian. Later on, the monk and scholar Hsuan Tsang was reported to have returned to China after a visit to north India with enough Buddhist relics and texts to load 20 horses. ${ }^{124}$ The traditional route of pilgrimage between India and China led from Peshawar to Kabul and over the Hindu Kush via Bamiyan, and then north and east across the Pamirs, around the desert of Takla Makan and across Lop Nor. ${ }^{125}$ A shorter route led through the mountain passes in the western part of Nepal into Taklakot in the Tibet Autonomous Region of China. ${ }^{126}$ However, Fa Hian and many other Chinese and Southeast Asian Buddhists seem to have used the sea route too, travelling in and out of the Bengali port of Tamralipti to reach the great university of Nalanda, ${ }^{127}$ which attracted students from all across Asia. ${ }^{128}$

120 The Birhadaranyaka Upanishad, 4.3.6. It is one of the principal Upanishads.

121 See Swami Krishnananda, The Brhadaranyaka Upanishad (The Divine Life Society Sivananda Ashram, Rishikesh, 1983), https://spiritual-minds.com/ easternrelgions/advaita/Brhadaranyaka.pdf.

122 Mahaparinibbana Sutta, DN 16, as cited in Khammai Dhammasami, "Wheel of Life: Philosophy and Ethics" in Jana Igunma and San San May (eds), Buddhism: Origins, Traditions and Contemporary Life (British Library, London, 2019), p 81.

123 Ibid.

124 John Keay, India - A History: From the Earliest Civilisations to the Boom of the Twenty-First Century (Harper Press, London 2010), p 161.

125 Ibid, p 114.

126 The Tibetan name "Takla Khar" is known in Nepali and Hindi as Taklakot.

127 Taxasheela or Takșaśilā (तक्षशिला in Sanskrit) in modern-day Punjab in Pakistan was considered to be the earliest university in the world. It became a noted centre of learning (including the religious teachings of Buddhism) at least several centuries BCE (circa eighth to sixth century BC) and attracted students from around the old world until the destruction of the city of Taxila in the fifth century. Kautilya's Arthashastra is said to have been composed in Takșaśilā.

128 History and Revival of Nalanda University, https://nalandauniv.edu.in/about -nalanda/history-and-revival. 


\subsection{Shintoism and Buddhism in Japan}

Shinto is an ancient local and indigenous religion of Japan, characterised by devotion to invisible spiritual beings and powers called kami, to shrines and to various rituals. It is not necessarily a philosophy or a way of explaining the world in the manner that Hinduism and Buddhism do. It is based on rituals through which human beings communicate with kami, which are not God or gods. For those who believe in Shintoism, kami are spirits that are concerned with human beings and that appreciate our interest in them and want us to be happy. These spirits or kami are worshipped in the hope that, if they are treated properly, they will intervene in our lives to bring benefits such as health, success and good exam results, just as Ganesh does to the Hindus. That is why many Japanese people have a tiny shrine-altar in their homes, as Hindus have a statue of Ganesh in their pooja places and as Buddhists have a statute of Buddha in or by the entrance to their homes.

After Buddhism was officially introduced into Japan in $552 \mathrm{CE}$, there emerged tendencies to interpret Shinto from a Buddhist viewpoint, and Shinto kami were viewed as protectors of Buddhism. Many shrines for tutelary kami were built within the precincts of Buddhist temples and kami were revered as deva, or "gods", similar to the reverence of deva or "gods" in Buddhism and Hinduism. Likewise, Buddhist temples were also built within Shinto shrine precincts, and Buddhist sutras (scriptures) were read in front of kami. Around the late eighth century, kami were thought to be avatars (incarnations) of buddhas (enlightened individuals who had attained liberation (moksha) from samsara) and bodhisattvas (buddhas-to-be). Kami were given different bodhisattva names; Buddhist statues were placed in the inner sanctuaries of some Shinto shrines; and in some cases, Buddhist priests were appointed to lead the management of Shinto shrines.

This is how the infusion of Shintoism and Buddhism or the local adaptation of Buddhism took place in Japan, and Buddhism began to influence the philosophical underpinning of Japanese life. Thus, from the beginning of the Kamakura period (1192-1333), ideas of Shinto-Buddhist amalgamation were formulated and promoted. This Buddhistic Shinto became popular for several centuries and was influential until its extinction at the Meiji Restoration. After the end of the Second World War, the state Shinto was disestablished and government financial support from public funds and all official affiliation with Shinto and Shinto shrines were also discontinued. Any state Shinto rites performed by the emperor were thenceforth regarded as the religious practices of the Imperial family and this detachment of Shintoism from the state was incorporated into the new post-war Japanese Constitution of 1947. 
Although Shintoism is an unofficial national religion, whose shrines draw visitors from across the country, it is more of a ritual than a religion in the proper sense of the term. Shintoism has no scriptures and Shintoist believers seem to draw their inspiration from the Buddhist scriptures. For this reason Shintoism has co-existed peacefully with Buddhism for centuries in Japan. Shintoism is mainly part of Japanese culture and life, with no missionary zeal and is thus rarely practised outside Japan. Since Shintoism has no canonical scriptures or commandments, the values of this religion are difficult to analyse. Although Shintoism teaches important ethical principles, in the absence of any canonical scriptures, it is difficult to assess its impact on the evolution of the notion of human rights for the purposes of this book. The Kojiki ("Records of Ancient Matters") and the Nihon shoki ("Chronicles of Japan") are regarded in a sense as sacred books of Shinto, they are also books about the history, topography and literature of ancient Japan. In sum, Shintoism was influenced by Buddhism, which in turn was influenced by Hinduism. Therefore, the wellspring of all major civilisations of the East proper is the main Hindu scripture, the Rig Veda.

\subsection{The Ideas of the Sanatana Dharma (Universal Code of Conduct)}

The Hindu-Buddhist world revolves around the theories of dharma or dhamma, but these ideas are complex. In simple terms, "dharma" means इज्याध्ययनदाना नि तपः सत्यं धृतिः क्षमा । अलोभ इति मार्गोडयं धर्मस्याष्टविधः स्मृतः ॥, which can be translated as: "living one's life according to the following eight virtues: performing the holy rituals (including performing yoga), studying, giving to charity, taking penance, realising truth, having courage, applying forgiveness, and preserving a lack of greed." 129 The Sanatana Dharma (Eternal Law or Universal Moral Code) was followed by the Vedic people in ancient times and came to be known later as Hinduism. There were various sects and faiths in existence during the Vedic era, and the Vedas sought to include them in their verses or mantras, so that the Vedas would be acceptable to all. This inclusive approach is embodied in the notion of Sanatana Dharma. The most fundamental of the philosophical concepts of the Sanatana Dharma are brahman, atman, karma (fruit of work) and transmigration. The doctrine of brahman-atman came to occupy centre stage due to the great philosophical and religious awakening of the Vedanta period - that is, towards the end of the Vedic period and the time of the composition of the Upanishads. However, a sense of duty or dharma towards all human beings remained central to the Sanatana Dharma

129 Hitopadesha, Mitralabha, as cited in Subhasita by Kalpana; https:// kalpanamuzumdar.wordpress.com/2013/09/16/subhashita-16-09-2013. 
and can be traced all the way back to the Rig Veda. For instance, the following prayer in the Rig Veda is addressed to god Varuna:

Against a friend, a companion, or a brother,

A fellow-clansman, or against a stranger,

Whatever trespass we have perpetrated,

Do thou, O Varuna, from that release us. ${ }^{130}$

None of the Vedas or other scriptures makes any mention of the term "Hindu", "Hinduism" or the "Hindu religion". The most significant of all Hindu scriptures is the Bhagavad Gita and this is the essence of Sanatana Dharma, rather than the Hindu dharma. "Hindu" was a term used by foreigners, such as the ancient Greeks and Romans, to describe the people living in and around the Indus Valley, and to the east of the Valley. The followers of the Vedic teaching did not call themselves Hindus. ${ }^{131}$ There are some other interpretations of the origins of the term "Hindu" - one of which states that those who regard the main letter and the sound ऊँ in Sanskrit, pronounced "Oom" or "Aoum", are "Hindus". ${ }^{132}$ This is regarded as a sacred sound and a spiritual symbol which signifies the essence of the ultimate reality, consciousness or Atman. However, this syllable is chanted either independently or before a spiritual recitation not only in Hinduism, but also in Buddhism and Jainism. Therefore, those who chant the Omkar or Om mantra known as as "pranav mantra" have been included within a broad definition of "Hinduism", and all of those who use this mantra are regarded as the followers of the Sanatana Dharma. In popular parlance, those who know the teachings of the Vedas, regard the Om mantra as the main mantra, have good character and commit no violence are regarded as Hindus.

In the strictest sense, neither Hinduism nor Buddhism is a "religion", and neither operates as an organised religion. ${ }^{133}$ For example, there is no religious

130 Rig Veda, V.85.7. See HD Griswold, The Religion of the Rigveda (Oxford University Press, Oxford, 1923), p 341.

131 For instance, although born into a Brahmin family, the present author does not identify himself as a Hindu. This is because he regards himself as a Vedic: a follower of the Vedas or the Sanatana Dharma based on the Vedas. He may very well tick the box for Hindus on a census, citizenship form or other occupational form; but this is in the absence of a separate box to tick for the followers of the Vedas.

${ }^{132}$ Laxmi Kanta Panthi, "Hindu Dhamra and Dharmic Culture" Aparna (a journal of the Bharadwaz Culture Promotion Centre, Kathmandu), Vol 1 (1), 2008, pp 41-55 at 41 (in Nepali).

133 According to Bhaktivedanta Swami Prabhupada, religion includes "four primary subjects, namely, pious activities, economic development, satisfaction of the senses, and, finally, liberation from material bondage". Bhaktivedanta Swami Prabhupada, Shrimad Bhagavatam (The Bhaktivedanta Book Trust, Watford, 2006) p 53. 
head in Hinduism as there is in other religions, such as the Pope for Catholics and the Ayatollah for Shia Muslims. The Dalai Lama is not the head of Buddhism; he is the spiritual leader of the Tibetan people. Furthermore, as illustrated above, there is no single universally accepted religious scripture for either Hindus or Buddhists, in the same way as the Bible exists for Christians and the Quran exists for Muslims. Buddhism does not even centre on one god. The core of its message is the attainment of salvation from suffering through the annihilation of desire. ${ }^{134}$

Hinduism and Buddhism are principally ways of life and philosophies of life, similar to Confucianism and Taoism, two ancient Chinese philosophies that also talk about "The Way". Buddhism resonated with the Chinese: it became one of three main religions in traditional China and the state religion in $379 \mathrm{CE}$. Buddhism still has the largest following of any religion in China today. Both Hinduism and Buddhism provide guidance to people on how to live a fulfilling, rewarding, dutiful and healthy life. Spiritual emphasis is placed on recommendations rather than on requirements about how people should live their lives, from dawn to dusk and from birth to death, for their own good and for that of society. Recommendations include vegetarianism; non-violence and asceticism; devotion and meditation; yoga in different forms, including bhakti (devotional) yoga, karma yoga (the path of action) and gyan (knowledge or wisdom) yoga; the attainment of inner happiness; the liberation of the soul; and the duties of one and all in society towards others. It is possible for a person to design his or her own menu of "dos and don'ts" from a choice of scriptures in order to guide his or her own daily practical and spiritual life; and this is considered perfectly acceptable. This is why there are so many sects within both Hinduism and Buddhism - which somewhat adds to the mystique of the East in the eyes of the people of the West, and to the complex and comprehensive character of both of these belief systems.

\section{CONCLUSIONS}

As can be seen from the analysis of the origins and development of Eastern belief systems, the scriptures of the East do incorporate early elements of human rights. At the core of the Hindu-Buddhist way of life is personal liberty, which is deeply entrenched in the notion of sanatana dhrama, which is found not only in Hinduism and Buddhism, but also in many other belief systems of the East. This may be one reason why the oldest religion or belief system of the world, Hinduism, has survived in South Asia for millennia, despite political

134 Norman Stone et al (ed), Harper Collins Atlas of World History (3rd edition) (Borders Press in association with Harper Collins, Ann Arbor, 1998), p 73. 
and social upheavals. Both Hinduism and Buddhism are cultures more than they are religions, entrenched in the psyche of the people. One of the main reasons for the survival of Hinduism is that it is "not only a religion but a philosophy and not only a religion and a philosophy but also a way of life". ${ }^{135}$ The theme woven throughout the analysis presented in this chapter is that Hindu values influenced Buddhist values, Buddhist values influenced Chinese values and Hinduism and Buddhism together influenced the values of much of Asia east of Iran; and they continue to inform to this day the thought processes of the people in these lands. It is the freedom or personal liberty and tolerance that Hinduism and Buddhism offer to the people, that has sustained these religions or belief systems and has influenced the development of the modern concept of human rights.

135 KRR Sastry, "Hinduism and International Law”, 117 Recueil des Cours (1966-I), p 507. 